\title{
Yaş ve Cinsiyetin Üriner Sistem Enfeksiyonu Etkeni Escherichia coli Kökenlerindeki Antibiyotik Direncine Etkisi
}

\section{The Effect of Age and Gender on Antibiotic Resistance of Escherichia coli Isolates of Urinary Tract Infection}

\author{
${ }^{1}$ Bahri TEKER, ${ }^{2}$ Nuray SEVER, ${ }^{3}$ Dilruba GARASHOVA \\ ${ }^{1}$ İstanbul Medipol Üniversitesi Tıp Fakültesi, İstanbul, Türkiye \\ ${ }^{2}$ Özel Medicana Tıp Merkezi Mikrobiyoloji Laboratuvarı, İstanbul,Türkiye \\ ${ }^{3}$ Özel Nisa Hastanesi Enfeksiyon Hastalıkları ve Klinik Mikrobiyoloji Kliniği, İstanbul, Türkiye \\ Bahri Teker :https://orcid.org/0000-0002-3350-7778 \\ Nuray Sever:https://orcid.org/0000-0002-5098-0065 \\ Dilruba Garashova: https://orcid.org/0000-0003-3376-8182
}

\section{ÖZ}

Amaç: $\mathrm{Bu}$ araştırmada tek merkezde üriner enfeksiyon etkeni olan E. coli kökenlerindeki antibiyotik direnç durumu ve geniş̧lemiş spektrumlu beta-laktamaz (GSBL) varl1ğının saptanması amaçlanmıştır.

Materyal ve Metot: Çalışmaya 2019 Ocak-2021 Nisan tarihleri arasında mikrobiyoloji laboratuvarına kabul edilen idrar kültürleri dahil edilmiştir. İdrar kültürlerinden izole edilen $E$. coli kökenlerinin duyarlılığ retrospektif olarak elde edildi. Değerlendirme Clinical and Laboratory Standards Institute (CLSI) kriterlerine göre Kirby-Bauer disk diffüzyon yöntemiyle yapılmıştır. Hasta verileri hastane kayıtlarından elde edildi.

Bulgular: Çalıș1lan 6216 idrar kültürünün 805 'inde (\% $12,9)$ üreme oldu. Üreyen bakterilerin 525 'i $(\% 65,2) \mathrm{E}$. coli idi. Erkeklerde artan yaşa paralel olarak idrar yolu enfeksiyonu sıklığının da arttığı izlendi. En fazla direnç görülen antibiyotikler sefalotin; \%80,0, ampisilin; \%68,9, amoksisilin klavulanat; \%47,4, ampisilin-sulbaktam; \% 37,9 , trimetoprim-sulfametoksazol; \%31,24 iken en duyar11 antibiyotikler ise amikasin; \%2,1, nitrofurantoin; \%1,7, imipenem; \%0,76 ve meropenem; \%0,57 idi. Kökenlerin 86'sında $(\% 16,3)$ genişlemiş spektrumlu beta-laktamaz (GSBL) varlığı tespit edilmiştir.

Sonuç: Merkezimiz verilerine göre üropatojen $E$. coli kökenlerinde antibiyotik direnci giderek yaygınlaşmaktadır. Bu durum akılcı antibiyotik kullanımının ve enfeksiyonların tedavisini planlarken mikrobiyolojik incelemelerin daha da önemli hale geldiğini göstermektedir.

Anahtar Kelimeler: Antibiyotik direnci, Escherichia coli, idrar yolu enfeksiyonu

\begin{abstract}
Objective: This study aims to determine the antibiotic resistance status and the presence of extended-spectrum beta-lactamase (ESBL) of E. coli, a causative agent of urinary tract infection.
\end{abstract}

Materials and Methods: The study included urine cultures admitted to the microbiology laboratory between January 2019 and April 2021. The susceptibility tests of $E$. coli strains isolated from urine cultures were obtained retrospectively. The evaluation was determined by the disk diffusion method of Kirby-Bauer according to Clinical and Laboratory Standards Institute (CLSI) criteria. Patient data were obtained from hospital records.

Results: 805 microorganisms were isolated from 6216 urine cultures. Of the 805 microorganisms, 525 (65.21\%) were $E$. coli. In parallel with the increasing age in men, the frequency of urinary tract infections also increased. Resistance rate of strains against cephalothin, ampicillin, amoxicillin-clavulanate, ampicillin-sulbactam, trimethoprim-sulfamethoxazole, amikacin, nitrofurantoin, imipenem and meropenem were $80.0 \%, 68.9 \%, 47.9 \%$, $37.9 \%, 31.24 \%, 2.1 \%, 1.7 \%, 0.76 \%$ and $0.57 \%$ respectively. Extended spectrum beta-lactamase (ESBL) was detected in $86(16.3 \%)$ of the strains.

Conclusion: According to our center, antibiotic resistance is increasingly common in E. coli uropathogens. This suggests that further microbiological research is becoming even more important in planning rational antibiotic and infection treatment.

Keywords: Antibiotic resistance, Escherichia coli, urinary tract infection

\footnotetext{
Sorumlu Yazar / Corresponding Author:

Bahri Teker

İstanbul Medipol Üniversitesi Tıp Fakültesi Enfeksiyon Hastalıkları

ve Klinik Mikrobiyoloji AD. İstanbul, Türkiye

Tel: +90532737585

E-mail: bteker@medipol.edu.tr
}

Yayın Bilgisi / Article Info:

Gönderi Tarihi/ Received: 11/05/2021

Kabul Tarihi/Accepted: 15/05/202

Atıf / Cited: Teker B ve ark. Yaş ve Cinsiyetin Üriner Sistem Enfeksiyonu Etkeni Escherichia coli Kökenlerindeki Antibiyotik Direncine Etkisi. Online Türk Sağlık Bilimleri Dergisi 2021;6(2):300-309. doi: 10.26453/otjhs.936270 


\section{GİRIŞ}

İdrar yolu enfeksiyonları (IYE) en yaygın enfeksiyon türlerinden biridir ve her y1l milyonlarca hastane başvurusundan sorumludur. Kadınlarda ömür boyu IYYE gelişme riski yüzde 50'den fazladır. Semptomlar arasında sık idrara çıkma, acil idrara çıma hissi, idrar yaparken ağrı ve yanma hissi bulunur. Eğer üst üriner sistem etkilenirse ateş ve yan ağrısı da eklenebilir. ${ }^{1}$

Günümüzde üropatojenler arasında artan antibiyotik direnci oranları göz önüne alındığında bir halk sağlığı tehdidi olarak kabul edilir. ${ }^{2}$ Üropatojenik E. coli kökenleri üriner sistem enfeksiyonlarının en sık etkenidir. ${ }^{3} \mathrm{Bu}$ enfeksiyonların rutin tedavisi için birçok ülkede beta-laktamlar, trimetoprim-sulfametoksazol, nitrofurantoin ve kinolonlar gibi antibiyotikler kullanılmaktadır. Ancak bu antibiyotiklerin kulanımlarının yaygınlaşması ve yanlış kullanılması, toplumlarda bunlara karşı direnç oranlarını artırmıştır. ${ }^{4,5}$

IYE tedavisi yapılırken bölgesel direnç paternlerinin bilinmesi çok önemli ve gereklidir. ${ }^{6}$ Bölgesel direnç paternleri bilinmeden yapılacak olan üriner sistem enfeksiyonlarının tedavisinde, başarısızlık riski yüksektir. Bölgesel direnç paternleri bilinirse ampirik tedavinin başarılı olma şansı çok daha yüksek olacaktrr. $^{7} \mathrm{Bu}$ araştırmada hastanemizden elde edilen E. coli kökenlerinde antibiyotik direncinin saptanması, cinsiyet ve yaşın antibiyotik direncine etkisi ve genişlemiş spektrumlu beta-laktamaz (GSBL) varlığının araştırılması amaçlanmıştır.

\section{MATERYAL VE METOT}

İstanbul Medipol Üniversitesi Girişimsel Olmayan Araştırmalar Etik Kurulu'ndan uygunluk onayı alınmıştır (Tarih 15/04/2021; Karar No: 800).

$\mathrm{Bu}$ çalışma İstanbul Bahçelievler ilçesinde Medipol Sağlık Grubu kuruluşları olarak faaliyet gösteren Özel Medicana Tıp Merkezi ve 55 yataklı Özel Nisa Hastanesinden oluşan sağlık kompleksinde retrospektif olarak yapılmıştır. Hastalar Özel Nisa Hastanesinde muayene edilmekte, alınan idrar örneklerinin mikrobiyolojik incelemeleri Medicana Tip Merkezi Laboratuvarında yapılmaktadır. Mikrobiyoloji laboratuvarına 1 Ocak 2019 ile 30 Nisan 2021 tarihleri arasında gönderilen idrar kültürleri çalışmaya alınmıştır.

İdrar kültüründe üretilen ve etken olduğu düşünülen bakterilerden sadece E. coli cinsi bakterilerin antibiyotik duyarlılık sonuçları çalışmaya dahil edilmiştir. İdrar kültüründe üreyen diğer bakteriler sadece sayı ve oran olarak belirtilmiş, antibiyotik duyarlılık test- leri çalışılmış ancak bu test sonuçları çalışmaya dahil edilmemiştir.

İdrar Örneklerin Toplanmasl: Sabah idrar örneği veya mesanede 4 saat ya da daha fazla beklemiş idrar, orta akım idrar toplama yöntemi ile alınmıştır. İdrar kabına örnek veremeyen çocuklarda pediatrik torba, sondalı hastalarda ise Foley katater örnekleri incelenmiştir. Steril idrar kabına alınan idrar, bekletilmeden koyun kanlı agara kantitatif ekim (koloni sayımı) yöntemiyle ve MacConkey besiyerine ise azaltma yöntemiyle ekilmiştir. Ayrıca santrifüje edilmemiş bir damla idrar, Gram boyama için lam üzerine damlatılmıştır. Besiyerine ekilen örnekler 37 C'de 18-24 saat inkübe edilmiştir. Üreme olmayan besiyerleri etüvde 48 saat bekletilmiştir. İdrarda tek tip $10^{4}$ veya daha fazla koloni oluşturan birim (kob)/mL üremesi, iki tip $10^{5} \mathrm{kob} / \mathrm{mL}$ üremesi ve IYYE semptomları olan hastalarda varlığında $10^{2} \mathrm{kob} / \mathrm{mL}$ üropatjen bakteri üremesi, anlamlı bakteriüri olarak kabul edilmiştir. Bu kriterleri karş1layan idrar kültürlerinde üretilen bakteriler için antibiyotik duyarlılık testleri çalışılmıştır. ${ }^{5,8}$

Bakteri Tanımlamast ve Antibiyotik Duyarlllk Testleri: Üreyen bakterilerin tanımlamaları API 20 E (Biomerieux) kiti ile yapılmıştır. Antimikrobiyal duyarlılıkları, Mueller-Hinton E agar (Biomerieux) besiyerinde disk difüzyon (BD BBL Sensi Disc) yöntemiyle belirlenmiştir. GSBL varlı̆̆ disk testiyle araştırılmıştır. Disklerin yerleştirilmesi ve zon çaplarının yorumlanmasında CLSI (Clinical Laboratory Standarts Institute) standartları kullanılmiştır. ${ }^{5}$

Ístatistiksel Değerlendirme: Hastalara ait veriler say1 ve yüzde (\%) olarak ifade edildi. Sürekli değişkenlerin analizi Student t-testiyle; kategorik verilerin analizi ise $\chi^{2}$ testiyle yapıldı. İstatistiksel hesaplamalar IBM SPSS Statistics for Windows. Version 22.0 (Statistical Package for the Social Sciences, IBM Corp., Armonk, NY, ABD) yazılımı aracıllğıyla gerçekleştirildi. Yapılan karşılaştırmalarda $p$ değeri 0.05 'ten küçük olan değişkenler istatistiksel olarak anlamlı kabul edildi.

\section{BULGULAR}

Hastanemiz mikrobiyoloji laboratuvarında 27 ay sürelik dönemde çalış1lan 6216 idrar kültürünün $805^{\prime}$ 'inde $(\% 12,9)$ üreme oldu. Üreyen bakterilerin 525 'i (\% 65,2) E. coli , 123'ü $(\% 15,3)$ Klebsiella spp., 24'ü (\%3) koagülaz negatif stafilokok ve 133 'ü $(\% 16,5)$ diğer bakterilerdi (Grafik 1).

İdrar kültüründe üreyen E. coli kökenlerine ait veriler 
retrospektif olarak derlenmiştir. Olguların yaş ortalamasi 36,5 25,6 (1-96) olup 450'si (\%85,7) kadın ve 75 'i $(\% 14,3)$ erkekti. Erkeklerin yaş ortalaması $(50,7 \pm 26,9)$ kadınların yaş ortalamasından $(34,1 \pm 24,5)$ yüksek bulundu. Aradaki fark istatistiksel olarak anlamlıyd $1(\mathrm{p}=0,001)$.

Erkeklerde artan yaşa paralel olarak idrar yolu enfeksiyonu sıklığının da arttığı izlenmiştir (Grafik 2).

E. coli kökenlerinin 86'sinda (\%16,3) GSBL varl1ğ1 tespit edilmiştir. En çok direnç görülen antibiyotikler sirasiyla, sefalotin $(\% 80,0)$, ampisilin $(\% 69,0)$ ve amoksisilin-klavulanik asit $(\% 47,4)$ olarak saptand1. En az direnç görülen antibiyotikler ise karbapenemler $(<\% 1,0)$, nitrofurantoin $(\% 1,7)$, fosfomisin $(\% 1,8)$ ve amikasindi $(\% 2,1)$ (Tablo 1) .

Amikasin, gentamisin, sefepim, siprofloksasin ve levofloksasine karşı erkeklerde kadınlara göre daha yüksek oranda direnç geliştiği saptanmıştır (Tablo 2). Çalışmamızda 65 yaş ve üzeri hastalarda tobramisin, gentamisin, siprofloksasin, levofloksasin, sefuroksim ve sefiksim direncinin 65 yaş altındaki hastalara göre daha yüksek olduğu saptanmıştır. Yaş grupları arasında GSBL direnci açısından anlamlı bir fark bulunmamıştır (Tablo 3).

\section{TARTIŞMA VE SONUÇ}

Çoklu ilaca dirençli (ÇİD) üropatojenlere yönelik tedavi seçenekleri sınırlı olduğundan, klinisyenlerin bu enfeksiyonlar için spesifik klinik ve epidemiyolojik risk faktörlerinin farkında olması gerekir. Mevcut literatüre göre, fosfomisin ve nitrofurantoinin aktivitesi ÇİD E. coli'ye bağlı idrar yolu enfeksiyonlarının çoğunda yeterlidir. ${ }^{9}$ Trimetoprim-sulfametoksazol klinik etkililiği korusa da direnç oranları uluslararası düzeyde artmaktadır. Beta-laktam antibiyotikler en yüksek direnç oranlarına ve en düşük klinik başarı oranlarına sahiptir.

ÇİD üropatojenler yüksek oranda florokinolon direncine sahiptir. Oysa florokinolonlar IYYE'ler için birinci basamak ajanlar olarak tavsiye önerilen ilaçlardandır. Lokal direnç oranlarını hesaba katmanın yanı sıra, direnç için hasta risk faktörlerinin ve farmakolojik ilkelerin dikkate alınması, ayakta tedavi edilen IYE'lerin ampirik tedavisine rehberlik etmeye yardımcı olacaktır. ${ }^{10}$ Araştırma sonuçlarımıza göre merkezimiz için, florokinolonların ampirik tedavide kullanılırken direnç açısından dikkatli olunması gerektiği düşünülmüştür.

IYYE kadınlarda daha sıktır. Genç ve seksüel olarak aktif kadınlarda insidans daha yüksektir. Ancak ilerleyen yaşla beraber erkeklerde de sıklık artmaktadır. Çalışmamızda literatürle uyumlu bir şekilde erkekler- de ilerleyen yaşla beraber İYE sıklığının arttığı saptanmıştır.

Antibiyotiklere karşı gelişen direnç tedavi seçimini etkiler. IYYE tedavisinde sık kullanılan trimetoprimsulfametoksazol, sefalosporinler ve amoksisilin merkezimiz için ilk seçenek olmaktan uzak görülmektedir. ${ }^{11}$ Araştırmamızın sonuçlarına göre fosfomisin ve nitrofurantoin alt üriner sistem enfeksiyonlarının tedavisinde kullanılabilecek rasyonel antibiyotikler iken, piyelonefrit ve ürosepsis gibi endikasyonlarda karbapenemler ve aminoglikozidlerin kullanılabilecek alternatifler olduğu sonucuna varılmıştır. Ancak ototoksisite ve nefrotoksisite gibi yan etkilerin aminoglikozidlerin kullanımını kısıtladığı düşünülürse, dirençli E. coli kaynaklı IYYE'de seçenekler oldukça azalmaktadır.

GSBL üreten kökenlerin, fosfomisin dışında denenen diğer tüm antibiyotiklere karşı GSBL üretmeyenlere göre daha yüksek oranda dirençli olduğu bulunmuştur. Ancak çalışmamızda fosfomisin direnci diğer antibiyotikerden farklı olarak GSBL üreten kökenlerde de düşük bulunmuştur. Ayrıca GSBL üreten bakterilerde karbapenemlere ve nitrofurantoine karş1 direnç, GSBL üretmeyenlere göre daha fazla görülse de bu direnç oranları düşük (imipenem için \%3,5, meropenem için \%2,3 nitrofurantoin için \%4,7) olduğundan, tedavi açısından bir sorun oluşturmamaktadır. Dolayısıyla alt üriner sistem enfeksiyonlarında fosfomisin ve nitrofurantoin kullanılabilecek ilaçlar arasindadir.

GSBL'ler gram negatif enterik basillerde görülen, karbapenemler hariç beta laktamları inaktive eden direnç enzimleridir. $\mathrm{Bu}$ enzimleri üreten $E$. coli ve Klebsiella spp.'ye karşı kullanılabilecek en etkili beta -laktam karbapenemlerdir. ${ }^{12,13} \mathrm{Bu}$ araştırmada 525 kökenin yaklaşık \%16,3'ünde genişlemiş spektrumlu beta-laktamaz varlığı gösterilmiştir. Verilerimize göre idrar yolu enfeksiyonu yapan kökenlerde genişlemiş spektrumlu beta-laktamaz sıklığ 1 ciddi orandadır ve üriner enfeksiyon tedavisi yapılırken hastanemizde bu bilgi dikkate alınmalıdır. Özellikle tekrarlayan IYYE öyküsü olan ve tedaviye cevapsız olgularda idrar kültürü ve antibiyotik duyarlılık sonuçlar1 mutlaka elde edilmeli ve tedavi bu sonuçlara göre düzenlenmelidir. ${ }^{13,14}$ Elazığ'da yapılan bir araştırmada E. coli ve Klebsiella spp. suşlarının \%40-47'sinde GSBL varlığı saptanmıştır. ${ }^{13} \mathrm{Bu}$ veriler sadece merkezimizde değil, ülkemiz genelinde GSBL sorununun yaygın olduğunu düşündürmektedir. Konuyla ilgili yeni araştırmalara ihtiyaç vardır.

Verilerimize göre GSBL üreten kökenlerde antibiyotik direnci anlamlı oranda daha fazladır. 
$\mathrm{Bu}$ durum antibiyotik direncine neden olan faktörlerle GSBL üretimine neden olan faktörlerin benzer olmasından kaynaklanabilir. Bu sonucu önemli buluyoruz. Bölgemizde şu anda \%16 düzeyinde olan GSBL direncinin yayılması yakın zamanda, idrar yolu enfeksiyonlarında tedavi alternatiflerimiz iyice kısıtlayacak ve bu endikasyonda tedavi zorluğuna neden olacaktır. ${ }^{15}$

Tablo 3'de ileri yaştaki hastaların bazı antibiyotiklere anlamlı oranda daha fazla dirençli olduğu gözlenmiştir. Bu durumun artan yaşla beraber daha fazla antibiyotiğe maruz kalınmasıyla ilgili olabileceğini düşünüyoruz. Özellikle ileri yaşla birlikte artan prostat hastalıkları ve daha fazla hastaneye yatma gereksiniminin daha fazla antibiyotiğe maruz kalmaya bu durumun da daha fazla dirence neden olabileceğini düşünüyoruz.

IYYE tanısı alan hastalara ampirik antibiyotik tedavisi verilebilmesi için uygulanacak ilaca karşı direnç oranı \%20'yi aşmamalıdır. ${ }^{5} \mathrm{Bu}$ nedenle Amerikan Enfeksiyon Hastalıkları Derneği (IDSA), bir bölgedeki İYE etkenleri ve bunların duyarlılıklarının bilinmesi gerektiğini bildirmiştir. Verilerimize göre ampisilin, amoksisilin, siprofloksasin gibi yaygın olarak kullanılan birçok ilaç \%20'nin üzerinde direnç oranlarına sahip iken amikasin, gentamisin, tobramisin gibi aminoglikozidler düşük direnç oranlarına sahiptir. Ancak ototoksik ve nefrotoksik yan etkilerin aminoglikozidlerin kullanımlarını sınırladığ göz ardı edilmemelidir. Nitrofurantoinin üriner sisteme geçişinin iyi olması ve düşük direnç oranı ile bölgemiz için alt üriner sistem enfeksiyonlarında bir alternatif olabileceği görülmüştür.

Güncel verilere göre seftriakson ve sefiksim gibi üçüncü kuşak sefalosporinler \%20'ye yakın direnç oranlarıyla halen bir alternatif gibi dursa da bu antibiyotiklere karşı direnç iyi izlenmeli ve gereksiz antibiyotik kullanımını durduracak stratejiler belirlenmelidir. Aksi takdirde yakın gelecekte, hayatı tehdit eden üst üriner sistem enfeksiyonlarında piyelonefrit vakalarında, tek alternatif olarak karbapenemler ve monobaktamlara mahkum kalabiliriz. ${ }^{5}$

Çalışmamızın retrospektif yapılmış olması, hastaların enfeksiyona yatkınlık oluşturacak komorbiditelerinin, antibiyotik kullanım ve tekrarlayan İYE öykülerinin bilinmemesi çalışmamızın eksiklikleri olarak sayılabilir.

Sonuç olarak çalışmamız, antibiyotik direncinin giderek yaygınlaştığını, artan direncin de hastanemizdeki kökenlerde sorun oluşturabilecek orana geldiğini göstermektedir. Bu durum akılcı antibiyotik kullanımını yaygınlaştıracak politikalara ihtiyaç olduğunu ve enfeksiyonların tedavisini planlarken mikrobiyolojik incelemelerin ihmal edilmemesi gerektiğini göstermektedir. Özelllikle tedavi endikasyonu olmayan asemptomatik bakteriüriler gereksiz yere antibiyotikle tedavi edilmemelidir. Üriner enfeksiyon tanısı doğru olarak konulmalı, hayatı tehdit etmeyen durumlarda karbapenemler gibi geniş spektrumlu antibiyotikler ilk seçenek olarak kullanılmamalı, idrar kültür-antibiyogram çalışmaları mutlaka yapılmalı ve başlanan antibiyotik tedavisi bu sonuçlara göre yeniden gözden geçirilmelidir.

Etik Komite Onayı: İstanbul Medipol Üniversitesi Girişimsel Olmayan Araştırmalar Etik Kurulu'ndan uygunluk onayı alınmıştır (Tarih: 15/04/2021, karar No: 800).

Çıkar Çatışması: Yazarlar çıkar çatışması bildirmemektedir.

Yazar Katkıları: Fikir - BT; Veri toplanması ve/veya işlemesi - BT, NS, Analiz ve/veya yorum - BT, DG; Yazıyı yazan - BT.

Hakem değerlendirmesi: Dış bağımsız.

Teşekkür: Zeynep DELIREİSOĞLU, Nuray YAMEN ve Kemal TOK başta olmak üzere Nisa Hastanesi Laboratuvarının tüm çalışanlarına emekleri için teşekkür ederiz.

\section{KAYNAKLAR}

1. Gallegos J, Márquez S, Morales K, Peña A. Etiologic and antibiotic susceptibility profile of the first episode of febrile urinary tract infection. Rev Chilena Infectol. 2013;30(5):474-479. doi:10.4067/S0716-10182013000500002.

2. Millner R, Becknell B. Urinary tract infections. Pediatr Clin North Am. 2019;66(1):1-13. doi:10.1016/j.pcl.2018.08.002.

3. Sancak EB. Tekrarlayan üriner sistem enfeksiyonları. Kadın ve İşlevsel Üroloji Bülteni. 2016;5 (46):46-49.

4. Asadi Karam MR, Habibi M, Bouzari S. Urinary tract infection: Pathogenicity, antibiotic resistance and development of effective vaccines against Uropathogenic Escherichia coli. Mol Immunol. 2019;108:56-67.

5. Sağlam HS, Öğütlü A, Demiray, Karabay O. Üriner enfeksiyonlarda toplum kökenli Escherichia coli'nin yeri ve gelişen antibiyotik direnci. Nobel Med. 2012;8(1):67-71.

6. Chen LF, Chiu CT, Lo JY et al. Clinical Characteristics and antimicrobial susceptibility pattern of hospitalized patients with community acquired urinary tract infections at a regional hospital in 
Taiwan. Healthc Infect. 2013;19(1):20-25. doi:10.1071/HI13033.

7. Ramakrishnan K, Venugopal J, Easow JM, Ravishankar M. Incidence, bacteriological profile and antibiotic resistance pattern of catheter associated urinary tract infections in a tertiary care hospital. J Pure Appl Microbiol. 2019;13(3):1549-1554. doi:10.22207/JPAM.13.3.27.

8. Klinik Mikrobiyoloji Uzmanlık Derneği (KLİMUD). Tıbbi mikrobiyoloji uzmanları için klinik örnekten sonuç raporuna uygulama rehberi. Üriner sistem örnekleri 2015. https:// www.klimud.org/public/uploads/files/urinersistem-ornekleri.pdf. Erişim tarihi 10 Mayıs 2021.

9. Bennett JE, Dolin R, Blaser MJ. Mandell, Douglas, and Bennett's principles and practice of infectious diseases. 8th ed. Elsevier, Philadelphia; 2014.

10. Walker E, Lyman A, Gupta K, Mahoney MV., Snyder GM, Hirsch EB. Clinical management of an increasing threat: outpatient urinary tract infections due to multidrug-resistant uropathogens. Clin Infect Dis. 2016;63(7):960-965. doi:10.1093/ cid/ciw396.

11. Samancı S, Çelik M, Köşker M. Çocukluk çağı idrar yolu enfeksiyonlarında antibiyotik direnci; tek merkez deneyimi. Türk Pediatr Arşivi. 2020;55(4):386-392.

12. Kara M, Elmaslar-Mert HT, Kuloğlu F, Akata F. Genişlemiş spektrumlu $\beta$-laktamaz üreten Escherichia coli'nin etken olduğu toplum kökenli üriner sistem infeksiyonlarında risk faktörlerinin değerlendirilmesi. Klimik Dergisi. 2020;33(1):5561. doi:10.5152/kd.2020.11.

13. Şenol A, Yakupoğulları Y, Şenol FF. Toplum kökenli üriner sistem infeksiyonlarında genişlemiş spektrumlu $\beta$-laktamaz üreten Escherichia coli ve Klebsiella spp. ve antimikrobiyal dirençleri. Klimik Derg. 2020;33 (2):163-168. doi:10.5152/kd.2020.34.

14. Cho YH, Jung S Il, Chung HS, et al. Antimicrobial susceptibilities of extendedspectrum beta-lactamase-producing Escherichia coli and Klebsiella pneumoniae in health careassociated urinary tract infection: Focus on susceptibility to fosfomycin. Int Urol Nephrol. 2015;47(7):1059-1066. doi:10.1007/s11255-0151018-9.

15. Loyola S, Concha-Velasco F, Pino-Dueñas J et al. Antimicrobial resistance patterns and dynamics of Extended-Spectrum $\beta$-Lactamase-producing uropathogenic in Cusco, Peru. Antibiot. 2021;10 (5):485. doi:10.3390/antibiotics 10050485. 


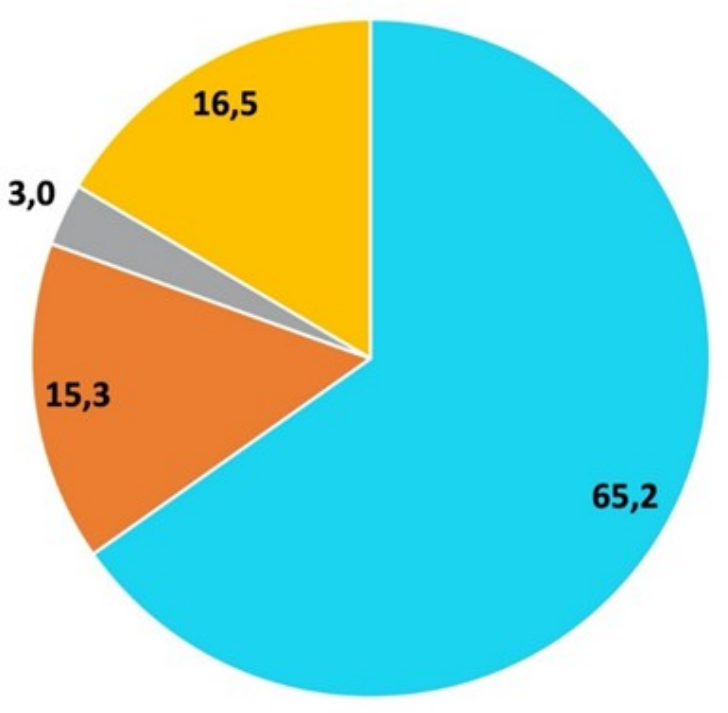

\section{=E. coli $=$ Klebsiella $=$ Koagülaz negatif stafilokok = Diğer}

Grafik 1. İdrar kültüründe üreyen bakteriler (\%). 


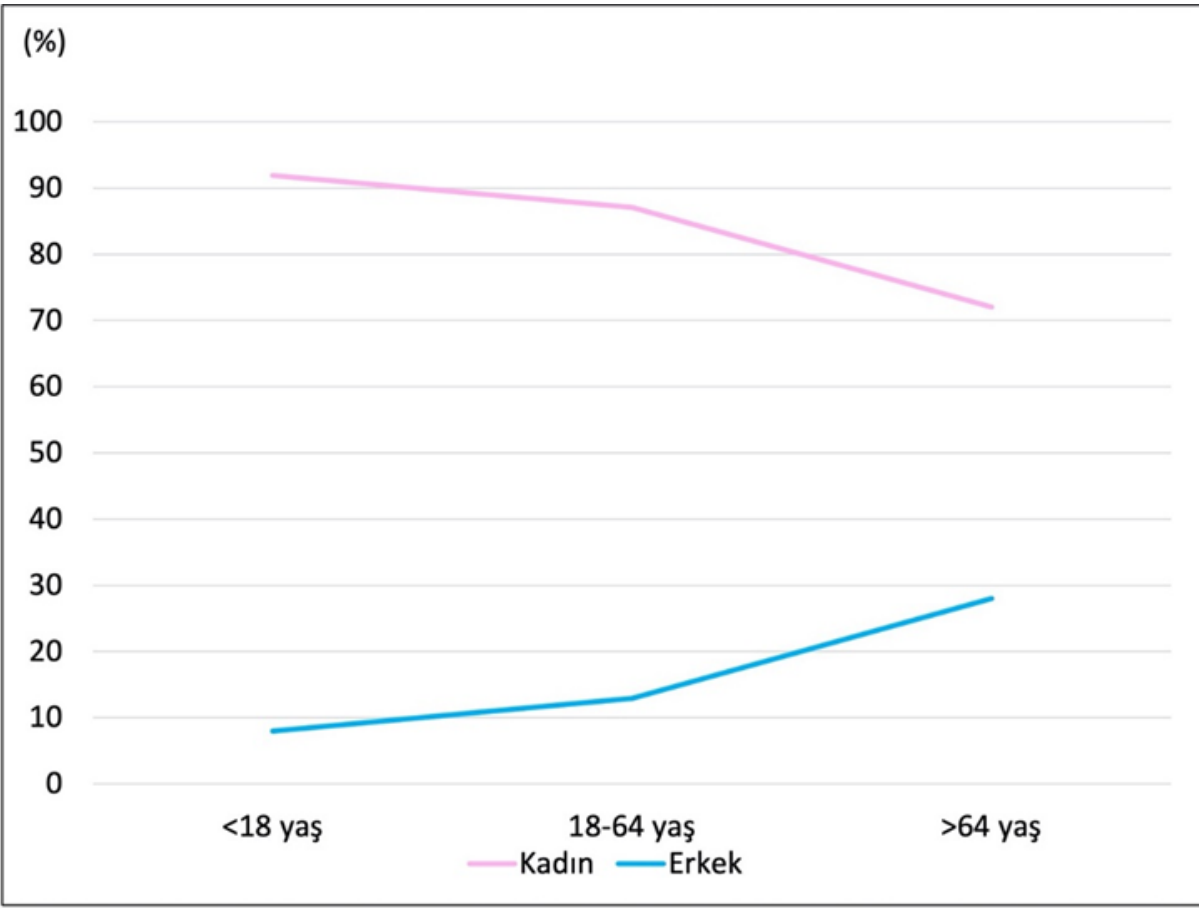

Grafik 2. İdrar kültüründe $E$. coli üreyen hastaların yaş gruplarına ve cinsiyete göre dağılımı (\%). 
Tablo 1. Antibiyotik direnç oranları.

\begin{tabular}{|l|c|c|c|}
\hline & & \multicolumn{2}{|c|}{ Dirençli } \\
\hline & Test edilen bakteri & $\mathrm{n}$ & $\%$ \\
\hline Sefalotin & 525 & 420 & 80,0 \\
\hline Ampisilin & 525 & 362 & 69,0 \\
\hline Amoksisilin-klavulanat & 525 & 249 & 47,4 \\
\hline Ampisilin-sulbaktam & 525 & 199 & 37,9 \\
\hline Trimetoprim-sulfametoksazol & 525 & 164 & 31,2 \\
\hline Sefuroksim & 525 & 139 & 26,5 \\
\hline Sefiksim & 525 & 137 & 26,1 \\
\hline Siprofloksasin & 388 & 89 & 22,9 \\
\hline Levofloksasin & 388 & 87 & 22,4 \\
\hline Seftriakson & 525 & 103 & 19,6 \\
\hline Tobramisin & 525 & 83 & 15,8 \\
\hline Aztreonam & 525 & 76 & 14,5 \\
\hline Gentamisin & 525 & 61 & 11,6 \\
\hline Seftazidim & 525 & 59 & 11,2 \\
\hline Sefepim & 525 & 36 & 6,9 \\
\hline Amikasin & 525 & 11 & 2,1 \\
\hline Fosfomisin & 394 & 7 & 1,8 \\
\hline Nitrofurantoin & 525 & 9 & 1,7 \\
\hline İmipenem & 525 & 4 & 0,8 \\
\hline GSBL & 525 & 85 & 16,2 \\
\hline
\end{tabular}

GSBL: Genişlemiş spektrumlu beta-laktamaz; n: Sayı. 
Tablo 2. Cinsiyet ve genişlemiş spektrumlu beta-laktamaz üretiminin antibiyotik direncine etkisi.

\begin{tabular}{|c|c|c|c|c|c|c|c|c|}
\hline & \multicolumn{2}{|c|}{$\begin{array}{c}\text { KADIN } \\
(450)\end{array}$} & \multicolumn{2}{|c|}{$\begin{array}{c}\text { ERKEK } \\
(75)\end{array}$} & \multirow[b]{2}{*}{ p değeri } & \multirow{2}{*}{$\begin{array}{c}\text { GSBL Pozitif } \\
(\mathbf{8 6})\end{array}$} & \multirow{2}{*}{$\begin{array}{c}\text { GSBL negatif } \\
(439) \\
\text { n (\%) }\end{array}$} & \multirow[t]{2}{*}{$\begin{array}{c}\text { p de- } \\
\text { geri }\end{array}$} \\
\hline & (n) & $(\%)$ & (n) & $(\%)$ & & & & \\
\hline Sefalotin & 358 & 79,6 & 62 & 82,7 & 0,533 & $84(\% 97,7)$ & $336(\% 76,5)$ & $<0,001$ \\
\hline Tobramisin & 66 & 14,7 & 17 & 22,7 & 0,079 & $41(\% 47,7)$ & $42(\% 9,6)$ & $<0,001$ \\
\hline $\begin{array}{l}\text { Trimetoprim- } \\
\text { sulfametoksazol }\end{array}$ & 135 & 30,0 & 29 & 38,7 & 0,134 & $51(\% 59,3)$ & $113(\% 25,7)$ & $<0,001$ \\
\hline Amikasin & 6 & 1,3 & 5 & 6,7 & $\mathbf{0 , 0 0 3}$ & $5(\% 5,8)$ & $6(\% 1,4)$ & 0,008 \\
\hline Seftazidim & 47 & 10,4 & 12 & 16,0 & 0,158 & $46(\% 53,5)$ & $13(\% 3,0)$ & $<0,001$ \\
\hline Ampisilin-sulbaktam & 164 & 36,4 & 35 & 46,7 & 0,091 & $70(\% 81,4)$ & $129(\% 29,4)$ & $<0,001$ \\
\hline Gentamisin & 47 & 10,4 & 14 & 18,7 & 0,040 & $30(\% 34,9)$ & $31(\% 7,1)$ & $<0,001$ \\
\hline Ampisilin & 306 & 68,0 & 56 & 74,7 & 0,248 & $83(\% 96,5)$ & $279(\% 63,6)$ & $<0,001$ \\
\hline Amoksisilin-klavulanat & 209 & 46,4 & 40 & 53,3 & 0,269 & $69(\% 80,2)$ & $180(\% 41)$ & $<0,001$ \\
\hline Seftriakson & 86 & 19,1 & 17 & 22,7 & 0,473 & $85(\% 98)$ & $18(\% 4,1)$ & $<0,001$ \\
\hline Sefepim & 26 & 5,8 & 10 & 13,3 & $\mathbf{0 , 0 1 7}$ & $28(\% 32,6)$ & $8(\% 1,8)$ & $<0,001$ \\
\hline Sefuroksim & 117 & 26,0 & 22 & 29,3 & 0,545 & $83(\% 96,5)$ & $56(\% 12,8)$ & $<0,001$ \\
\hline Meropenem & 3 & 0,7 & 0 & 0,0 & 0,478 & $2(\% 2,3)$ & $1(\% 0,2)$ & 0,018 \\
\hline Siprofloksasin & 65 & 20,1 & 24 & 37,5 & 0,002 & $37(\% 56,1)$ & $52(\% 16,1)$ & $<0,001$ \\
\hline Sefiksim & 114 & 25,3 & 23 & 30,7 & 0,330 & $84(\% 97,7)$ & $53(\% 12,1)$ & $<0,001$ \\
\hline Levofloksasin & 63 & 19,4 & 24 & 37,5 & 0,001 & $37(\% 56,1)$ & $50(\% 15,5)$ & $<0,001$ \\
\hline Fosfomisin & 8 & 2,4 & 0 & 0,0 & 0,240 & $2(\% 2,9)$ & $5(\% 1,5)$ & 0,424 \\
\hline Aztreonam & 62 & 13,8 & 14 & 18,7 & 0,265 & $60(\% 76,7)$ & $10(\% 2,3)$ & $<0,001$ \\
\hline İmipenem & 4 & 0,9 & 0 & 0,0 & 0,412 & $3(\% 3,5)$ & $1(\% 0,2)$ & 0,001 \\
\hline Nitrofurantoin & 8 & 1,8 & 1 & 1,3 & 0,784 & $4(\% 4,7)$ & $5(\% 1,1)$ & 0,022 \\
\hline GSBL & 70 & 15,6 & 15 & 20,0 & 0,360 & & & \\
\hline
\end{tabular}

GSBL: Genişlemiş spektrumlu beta-laktamaz; n: Sayı. 
Tablo 3. Antibiyotik direncinin yaş gruplarına göre dağılımı.

\begin{tabular}{|c|c|c|c|c|}
\hline & $<18$ yaş & 18-64 yaş & $>64$ yaş & p değeri \\
\hline Sefalotin & $106(\% 77,4)$ & $237(\% 80,3)$ & $77(\% 82,8)$ & 0,587 \\
\hline Tobramisin & $16(\% 11,7)$ & $45(\% 15,3)$ & $22(\% 23,7)$ & 0,047 \\
\hline $\begin{array}{l}\text { Trimetoprim- } \\
\text { sulfametoksazol }\end{array}$ & $41(\% 29,9)$ & $89(\% 30,2)$ & $34(\% 36,6)$ & 0,474 \\
\hline Amikasin & $2(\% 1,5)$ & $4(\% 1,4)$ & $5(\% 5,4)$ & 0,051 \\
\hline Seftazidim & $14(\% 10,2)$ & $31(\% 10,5)$ & $14(\% 15,1)$ & 0,437 \\
\hline Ampisilin-sulbaktam & $62(\% 45,3)$ & $99(\% 33,6)$ & $38(\% 40,9)$ & 0,053 \\
\hline Gentamisin & $9(\% 6,6)$ & $36(\% 12,2)$ & $16(\% 17,2)$ & 0,042 \\
\hline Ampisilin & $98(\% 71,5)$ & $196(\% 66,4)$ & $68(\% 73,1)$ & 0,359 \\
\hline $\begin{array}{l}\text { Amoksisilin- } \\
\text { klavulanat }\end{array}$ & $69(\% 50,4)$ & $129(\% 43,7)$ & $51(\% 54,8)$ & 0,126 \\
\hline Seftriakson & $28(\% 20,4)$ & $50(\% 16,9)$ & $25(\% 26,9)$ & 0,105 \\
\hline Sefepim & $8(\% 5,8)$ & $17(\% 5,8)$ & $11(\% 11,8)$ & 0,112 \\
\hline Sefuroksim & $43(\% 31,4)$ & $63(\% 21,4)$ & $33(\% 35,5)$ & 0,008 \\
\hline Meropenem & $1(\% 0,7)$ & $2(\% 0,7)$ & - & 0,721 \\
\hline Siprofloksasin & - & $52(\% 17,6)$ & $37(\% 39,8)$ & $<0,001$ \\
\hline Sefiksim & $40(\% 29,2)$ & $63(\% 21,4)$ & $34(\% 36,6)$ & 0,009 \\
\hline Levofloksasin & - & $50(\% 16,9)$ & $37(\% 39,8)$ & $<0,001$ \\
\hline Fosfomisin & $1(\% 16,7)$ & $5(\% 1,7)$ & $1(\% 1,1)$ & 0,673 \\
\hline Aztreonam & $18(\% 13,1)$ & $38(\% 12,9)$ & $20(\% 21,5)$ & 0,105 \\
\hline İmipenem & - & $4(\% 1,4)$ & - & 0,208 \\
\hline Nitrofurantoin & $2(\% 1,5)$ & $3(\% 1)$ & $4(\% 4,3)$ & 0,1 \\
\hline GSBL & $20(\% 14,6)$ & $44(\% 14,9)$ & $22(\% 23,7)$ & 0,112 \\
\hline
\end{tabular}

GSBL: Genişlemiş spektrumlu beta-laktamaz. 